\title{
RACE IN THE SHIPBUILDING INDUSTRY: CASES OF SOUTH KOREA, JAPAN AND CHINA
}

\begin{abstract}
Soo Kee Tan
The shipbuilding industry is enormously important to the South Korean economy. It serves as the backbone of survivals of many other industries in Korea. The success story of the Korean shipbuilding industry is the national pride for the Korean people because it started from scratch in the 1970s and reached the world number one position in just three decades. Top Korean shipbuilders such as Hyundai Heavy Industries, Daewoo Shipbuilding and Marine Engineering and Samsung Heavy Industries have taken the top three ranking positions in the world as the finest and largest global shipbuilders. In the early 2000s, Korean shipbuilders were dominant enough to command nearly 40 percent of the global production in shipbuilding. Nonetheless, the situation has changed with the emergence of new competitors in the market. Chinese shipbuilders and the revived Japanese shipbuilders are now strong contenders in the industry and a threat to the Korean shipbuilders. Since 2014, the global shipping market has been hit hard with the sudden drop in crude oil price, and this change in demand tremendously affected the Korean shipbuilding industry. The Korean shipbuilding industry nearly collapsed in 2016, which prompted huge interventions from the Korean government. The unexpected changes within the shipbuilding industry shocked the Koreans. This article has two objectives. First, it aims to study what caused the sudden shift in the Korean shipbuilding industry. Second, to what extent have the Chinese and Japanese shipbuilders affected the Korean shipbuilders, and what are their current status in the global market? Ultimately, the article looks at the future faced by Korean shipbuilders due to the competition from China and Japan.
\end{abstract}

Keyword: Shipbuilding industry, competition, Korea, Japan, China

\section{Introduction}

The shipbuilding industry is a dynamic and competitive sector. As an assembly industry, shipbuilding has extensive linkages with more than 50 other industries. It is the key industry that helps many heavy machinery manufacturers to prosper, and it plays an important role in both the commercial and military sectors, which are closely related to many other industries such as steel, electronics, chemicals, glass production, logistics, storage, and port services. The industry provides a platform on which skills in various economic activities are developed, such as those pertaining to machining, naval architecture, metallurgy, engineering and welding and fabrication. In view of its importance, many countries have identified it as a strategic industry in their national development plans.

With fluctuating demands in the market, the financial performance of shipbuilding industry is cyclical, often impacted by an overcapacity every few years. Since 1896, the industry has encountered more than nine major cycles, each with more than 40 percent reduction in demand. Smaller fluctuations of 10 to 20 percent happens every seven to ten years. ${ }^{1}$ When a major cycle arrives, it wipes out many inefficient and weak players from the market, and even forces major

\footnotetext{
1 “An Assessment of Maritime Technology and Trade," Washington, D.C.: U.S. Congress, Office of Technology Assessment, OTA-O-220, October 1983, p.87
} 
establishments to restructure operations. During this painful process, some shipbuilders grow stronger, but others totally disappear from the market.

Currently, the top two largest shipbuilders in the world are from Korea, namely Hyundai Heavy Industries and Daewoo Shipbuilding and Marine Engineering. Their success as well as failure is extremely important to the Korean economy. These conglomerates are too big to fail because they owe a lot of money to the banks in Korea, contribute almost 7 percent of Korea's exports and provide 5 percent of the country's total employment. Currently more than 200,000 workers in Korea are employed in the shipbuilding industry. As a testimony of its importance, the Korean government initiated a massive financial rescue package to save the industry during the crisis period of 2016. During this most recent hard-hit period that happened last year, the government poured a humongous amount of money into the ailing shipbuilding companies so as to avoid a total collapse of the industry. The government's biggest objective was to prevent the bitter experience of the European shipbuilders in the 1980s where the European government financial rescue plan failed to revitalize the industry. ${ }^{2}$

In the past two decades, South Korean shipbuilders were widely recognized as the world's best shipbuilders. The levels of Korean shipbuilding quality, technology know-how and the competitiveness are almost unbeatable. The success story of Korean shipbuilders is one of a national pride because it began from the scratch and hit the position of number one globally within decades. Nonetheless, the situations changed when new competitors joined the race. The emergence of Chinese shipbuilders and revival of the Japanese shipbuilders have posed a strong challenge to the Korean shipbuilders. When the global shipping market was hit hard with the sudden drop in crude oil price since 2014 and due to the weak global trade, the Korean shipbuilding industry plunged into a deep crisis in 2016. The market sentiment was extremely weak when none of the Korean shipbuilding companies were able to win a single order in the month of April 2016, for the first time in history. ${ }^{3}$ The industry almost collapsed, which required huge intervention from the Korean government. The unforeseen changes of the shipbuilding industry shocked the Korean populous as it witnessed massive layoffs in the industry. To study the prospect of the industry, this study aims to address a few questions. Firstly, it examines the market trends and current status of the global shipbuilding industry. Secondly, it analyzes the impact of the current crisis of the shipbuilding industry which focuses on South Korea. Thirdly, it examine the challenges posed by Chinese and Japanese rivals for the Korean shipbuilding companies.

\section{A Glance at the Global Shipbuilding Industry}

The market trends of the global shipbuilding industry has undergone substantial changes in the post-World War II period. It has experienced a few major cycles since 1950s with changes in global market demands (as shown in the Figure 1). The latest boom happened in the early 2000s and reached its peak in 2008. Due to the strong market demands and limited capacity, the world's shipping order book to sales ratio increased to 3.5 times in 2005, higher than the historical average

\footnotetext{
2 "Can the South Korean State Arrest What Looks to be an Imminent Crisis in the Shipbuilding Industry?" The Diplomat, June 29, 2016, available from https://thediplomat.com/2016/06/south-koreas-shipbuilding-crisis/

3 "Why the Korean Shipbuilding Sector is Struggling and how the Industry can Rebound?" KBS World, May 16, 2016, available from http://world.kbs.co.kr/english/program/program economyplus detail.htm?no=5518
} 
of 2.1 (between 1982-2002). ${ }^{4}$ The market movements of the shipbuilding industry are closely tied to the trends of world trade. When the global financial crisis hit the shipping market in 2008, the new order book for shipbuilding plunged significantly as shown in Figure 1. The shipbuilding industry was badly affected in 2008. After the 2008 crash, it took a few years for the industry to pick up again in 2011 with a new record of 100.0 million GD. After reaching the peak, the weakening world trade and oil crisis weighed down the shipbuilding industry; the market demands for new ships continued to drop until 2016. Because shipbuilding industry is cyclical in nature, government support during the down trend periods plays a significant role in keeping the shipbuilders afloat. This has been proven in cases of Japanese, Korean and Chinese shipbuilders.

Figure 1 World Shipbuilding 35 Year Cycle

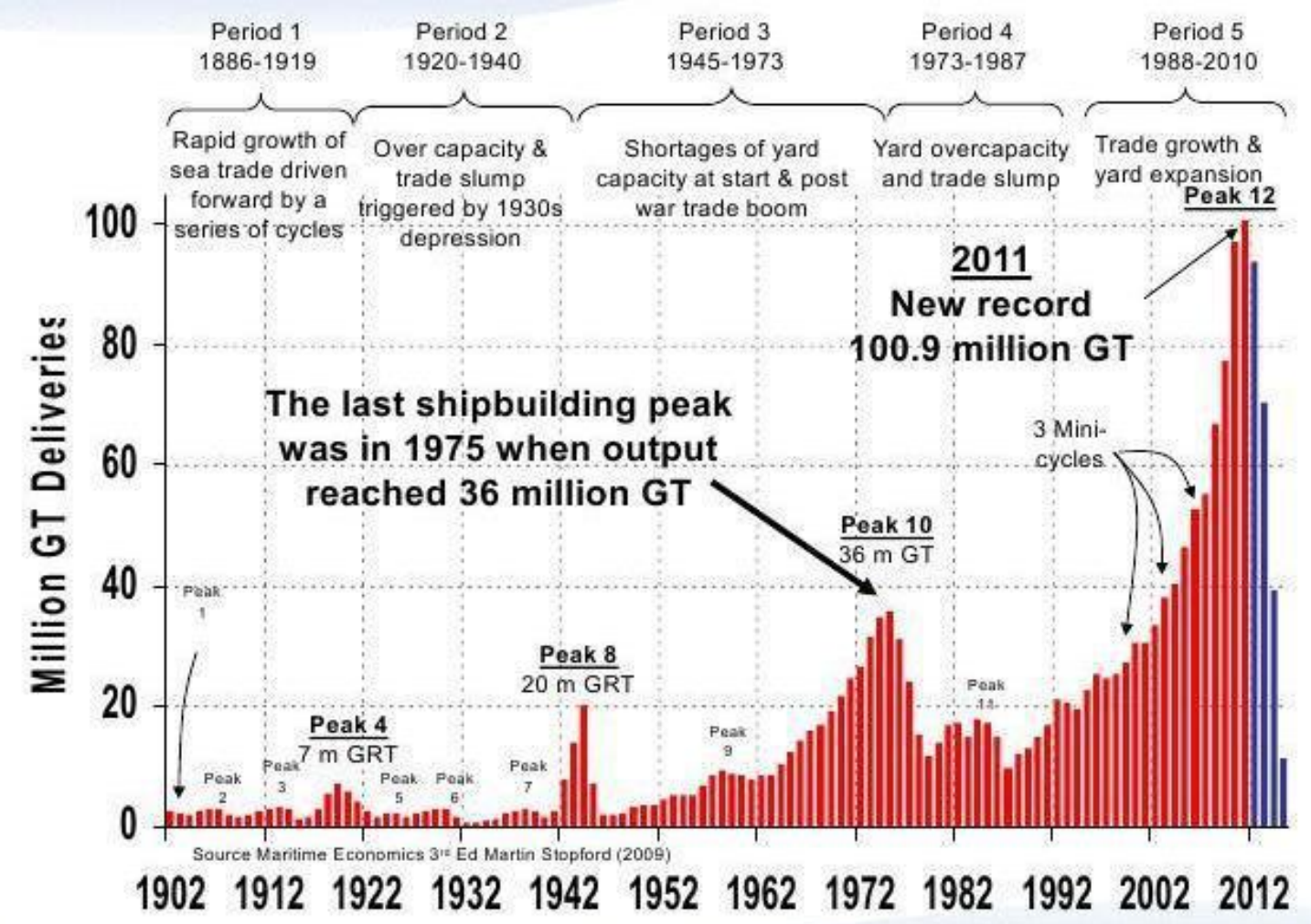

Source: Clarkson Research Service, 2017.

According to the Clarkson Research's report, the current market is on the downtrend, which may take another few years for it to recover. The report noted that the current cycle experienced a more gradual fall in deliveries, declining 34\% between 2010 and $2014 .^{5}$ The market research predicts that orders for an estimated 1,300 ships are expected to be placed in 2018, and the number may increase to 1,667 units in 2019 and 1,869 units in $2020 .^{6}$ According to this report, 353 shipbuilders have a vessel (1,000 GT or above) on order currently, but almost half of these

4 "Global shipbuilding: An overview," Equity Master, Feb 15, 2017, available from https://www.equitymaster.com/detail.asp?date=2/15/2007\&story=1\&title=Global-shipbuilding-An-overview

${ }^{5}$ Clarksons Research, accessed Dec 1, 2017, available from https://clarksonsresearch.wordpress.com/category/shipbuilding-2/

6 "New Shipbuilding Orders to Rebound Sharply in 2018: report," Hellenic Shipping News, October 18, 2016, available from http://www.hellenicshippingnews.com/new-shipbuilding-orders-to-rebound-sharply-in-2018-report/ 
shipyards failed to win a contract since 2016. The overcapacity, which characterizes the global shipbuilding industry is clearly the cause for the major crash. ${ }^{7}$ Oversupplies from shipbuilders worldwide, particularly from China dragged down the shipbuilding pricing. The crisis caused hundreds of shipbuilders in China and South Korea to close businesses; the downturn particularly affected the shipbuilders that speculated on the market, who took chances to earn profits during the boom period. As indicated in Figure 2, the new order for shipbuilding dropped significantly from 103200 million compensated gross tons in 2013 to 1880 million compensated gross tons in 2016; this is an indication of more than 98 percent drop during this period. The new order received in 2016 was even lower compared with 2009 crisis year, which stood at 33600 million compensated gross tons.

Figure 2 Shipbuilding's World New Order (in millions of compensated gross tons)

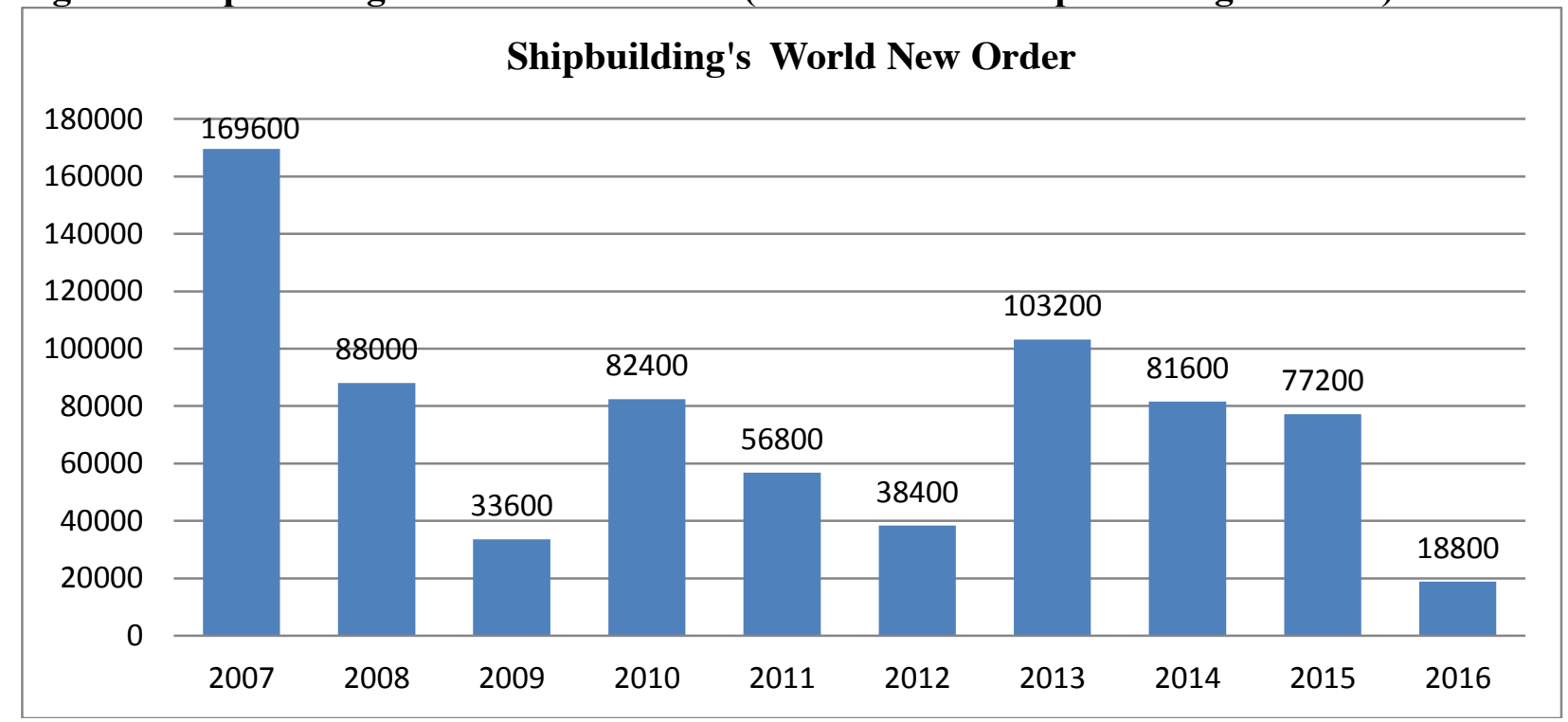

Source: Created by the author using data from the Shipbuilders Association of Japan Note: Ship size coverage 100 gross tonnage and over

Historically, global shipbuilders received an annual average of 2,200 new ship orders over the past 20 years. ${ }^{8}$ The fortune of the industry is closely tied with the international trade and seaborne trade growth. Because of its profitability and high linkages to many industries, many countries have joined the race to become a global player in shipbuilding. Thus, the shipbuilding industry went through a tremendous geographical shift in terms of the relative positions of the major shipbuilding nations over the past six decades. Before World War II, Britain was the world's leading shipbuilding nation; after the war, it lost ground to continental Europe, particularly to Germany. With rising production costs, particularly high wages, the European shipbuilding industry faced tough competition from Japanese shipbuilders since the 1950s and the South Korean shipbuilders since the 1980s. Consequently, the global market share of the European players shrunk from $28 \%$ in 1983 to $7 \%$ in 2005. Hundreds of shipyards in Europe and U.S were forced to close down and filed for bankruptcy. A prime example is the British shipbuilding industry,

\footnotetext{
${ }^{7}$ Clarksons Research, accessed Dec 1, 2017, available from https://clarksonsresearch.wordpress.com/category/shipbuilding-2/

8 "New Shipbuilding Orders to Rebound Sharply in 2018: report," Hellenic Shipping News, October 18, 2016.
} 
which suffered badly from global competition. The British yards had the facility to build all types and sizes of commercial vessels, but today only a small number of them specialize in repair works, yachts and defense contracts. The labour costs and government interventions are major factors for causing the geographical shift in terms of the relative global positioning.

In the 1950s, Japan emerged as the strongest shipbuilding nation in the world. The state support was a major force in helping the Japanese builders to build the foundation of their industry. To rebuild Japan's economy after World War II, shipbuilding was identified as one of the strategic industries by the Japanese government. A planned shipbuilding program was started with favourable financing loans and series of supporting measures from the 1950s. This state program assisted the Japanese shipbuilders with a stable source of demand in the 1950s and 1960s. When the world orders for new ships increased, Japanese companies slowly captured the world market share and overtook the British as the world number one shipbuilding nation in 1956. For instance, Japan's share in the global shipbuilding market (in terms of completions) increased from 22 percent in 1960 to 53 percent by $1984 .{ }^{9}$ There were 5000 shipyards in Japan in the 1980s to meet the expanding demand from the world market. Japanese shipbuilders were able to hold on to the top position until 1999 although they went through a very hard time in the mid-1970s and late 1980s. The state support again was a key factor for keeping the Japanese shipyards afloat with a series of restructuring programs and domestic market support. Until today, the major shipbuilding companies in Japan include Imabari Shipbuilding, Oshima Shipbuilding, Tsuneishi Shipbuilding and Mitsubishi Heavy Industry. Japanese shipbuilders are well known for constructing sophisticated offshore vessels and eco-friendly ships.

Nonetheless, when the labour cost in Japan increased substantially from the early 1990s due to the appreciation of the Japanese Yen, local shipbuilders started to lose their cost competitiveness to other Asian counterparts. Korean shipbuilding companies emerged as a tough competitive players in the global market. By learning from Japan's industrial strategy, the Korean government embarked on a similar shipbuilding program to develop its own shipbuilding industry. With extensive state support and aggressive business strategies, Korean shipbuilders improved their global position, rising from less than one percent of completions in 1975 to nearly 22 percent in 1994, and 39 percent in 2008. With worsening cost competitiveness for Japan, shipbuilding cost in Japan was 25 percent higher than that of South Korea in the mid-1990s. Japanese shipbuilders finally lost their number one global ranking position to South Korea in 2000. When the 2008 global financial crisis hit world trade, Japanese shipbuilding companies were affected badly and suffered for a long time from a significant decline in demand. The Japanese's world market share (in terms of completions) slid from 40 percent in 1999 to 19 percent in 2011. By this time, other market players, particularly those from South Korea successfully beat Japanese companies. Since then, the major Korean shipbuilders such as Hyundai Heavy Industries, Samsung Heavy Industries, and Daewoo Shipbuilding and Marine Engineering have remained the front runners of the global shipbuilding race.

By following the Japanese model, South Korea successfully built its shipbuilding capacity and became the top shipbuilding nation in the early 2000s. However, the entry of China into the industry changed the market environment in recent years. By repeating Japan's and Korea's development model, China joined the race with large state-supported programs. From 2001, China aggressively expanded its shipbuilding capacity as shown in Figure 3. China's global market share

\footnotetext{
9“Japanese Shipbuilding," Global Security, accessed on October 3 2017, available from https://www.globalsecurity.org/military/world/japan/industry-shipbuilding.htm
} 
(for completions) grew from 6 percent in 2000 to 38 percent in 2010. Between the years 2007 and 2010 , the market share rose substantially from $18 \%$ to $39 \%$. The main reason for the big shift is the cost competitiveness. The history of the shipbuilding market repeated itself; cost competitiveness was again the major factor in reshaping the landscape of the global shipbuilding industry. The 2008 market crisis, which affected the Korean shipbuilding industry badly, created a golden opportunity for Chinese shipbuilders to capture a larger portion of market share. The appreciation of Korean won and high labour cost in South Korea were the main disadvantages for Korean companies. Thus, Chinese shipbuilders have slowly but steadily taken away a larger market share of the new building contracts. Since 2010, China has overtaken South Korea as the largest shipbuilding nation in the world, as shown by the figures below. Today, the market share of China continues to expand, particularly in raking in the new orders.

\section{Figure 3 Share of Global Shipbuilding Market (Completions)}

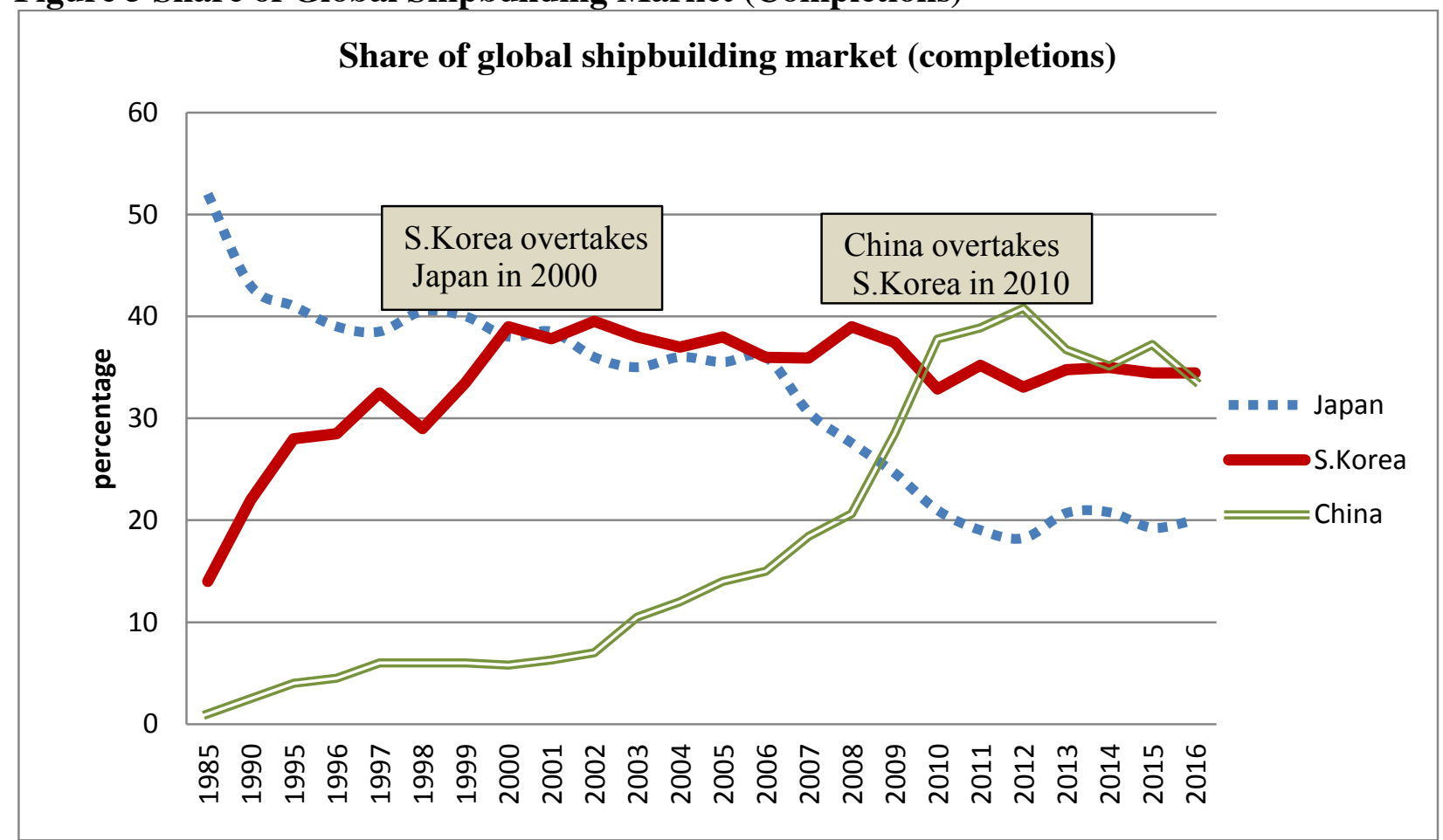

Source: Created by the author using data from IHS and The Shipbuilders' Association of Japan 
Figure 4 Shipbuilding New Orders: South Korea, China and Japan (2007-2016)

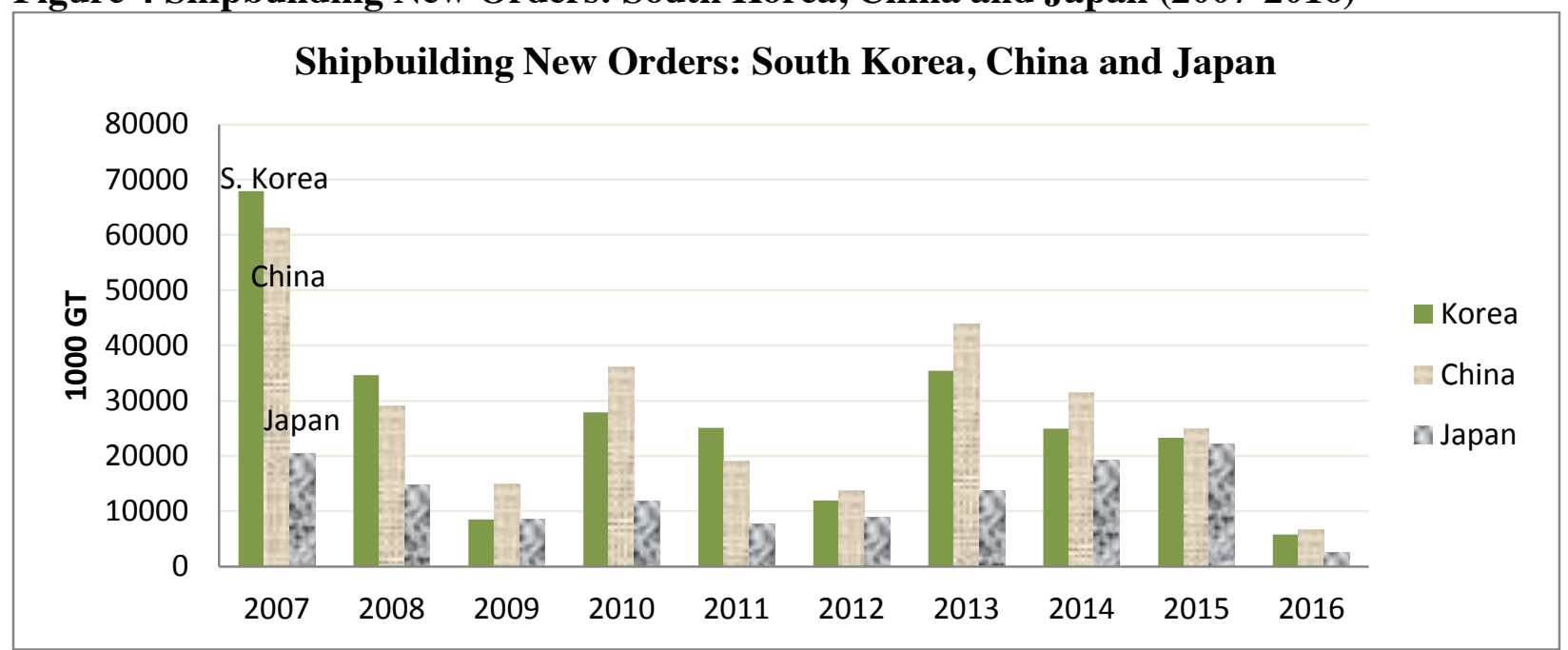

Source: Created by the author using data from IHS and The Shipbuilders' Association of Japan

Japan controlled more than $50 \%$ of the global shipbuilding industry in the 1980 s but now ranks third after China and South Korea. China ranked number one in terms of registering new orders and world order book as of December 2016, according to Clarkson Research data (quoted in $\mathrm{CANSI}^{10}$ ). In terms of the volume of completions, South Korea accounted for the largest market share with $35.4 \%$, followed by China 32\% and Japan 20.4\% (see Figure 5). ${ }^{11}$

Figure 5 Largest Shipbuilding Nations as of Dec 2016

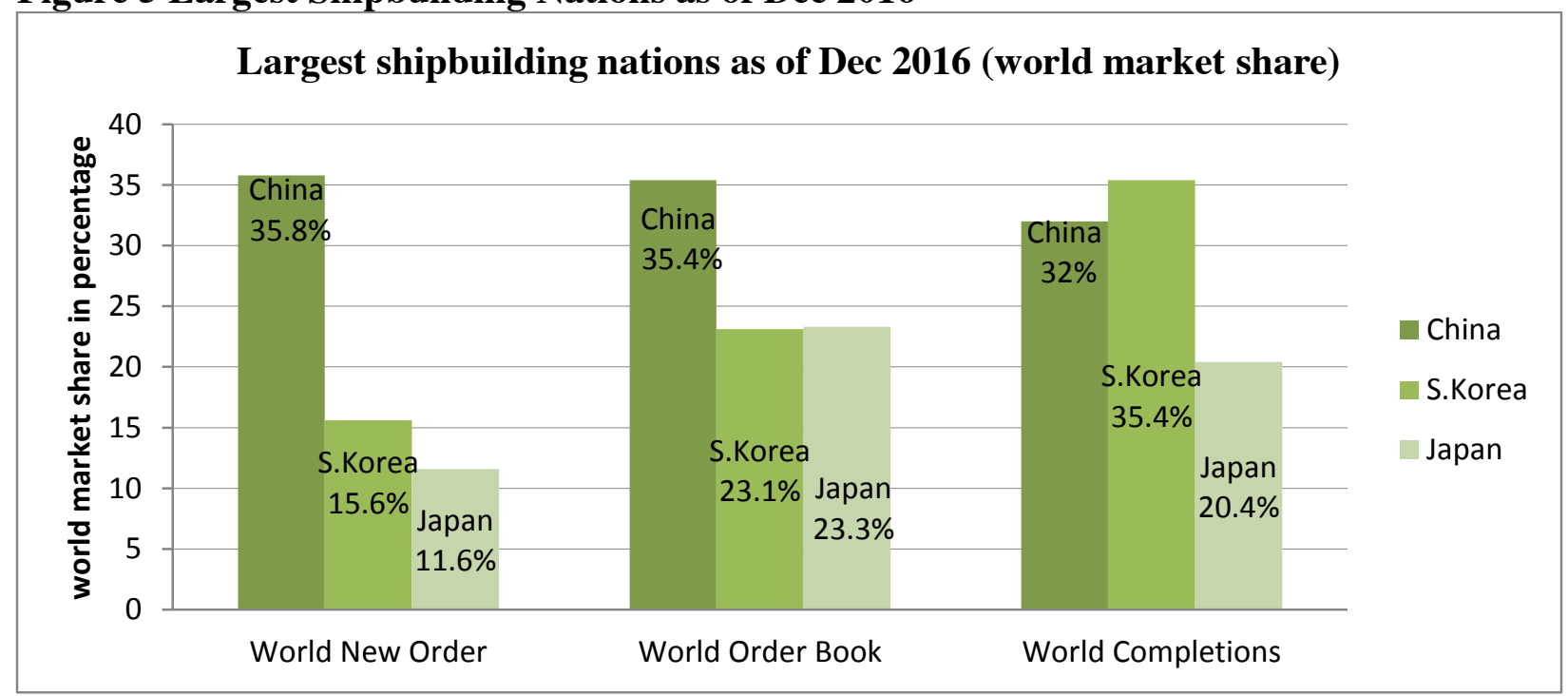

Source: Created by author using data from CANSI (2017)

\footnotetext{
${ }^{10}$ CANSI China, accessed on Dec 10 2017, available from http://www.cansi.org.cn/index.php/Information/detail?id=517

11 "Lower Yen, Green Tech Fuel Resurgence," Nikkei Asian Review, Dec 8, 2014, available from https://asia.nikkei.com/Business/Trends/Lower-yen-green-tech-fuel-resurgence
} 
The highest number of new orders and world order book of China foresees a better position for China in the immediate future. Based on the latest statistics data (Jan-Nov 2017) from CANSI, China continues to be the leader in the world market share for world new orders, order book and completions. The achievement of China in gaining new orders in the year 2017 is astonishing; it controls more than 40 percent of the world market share. South Korea is in a better position compared with the year 2016; the country records more than 10 percent rise. Japan's world market share in all the categories drops slightly in comparison with that of the year 2016. China continues to move up aggressively in many aspects. According to the latest released report of the world's Great Ship for the year 2017 (by Maritime Reporter and Engineering News), three ships are made in China, two ships are made by South Korea's Daewoo, and one ship is made by Japan's Marine United Corporation. This ranking shows that China has improved its competitiveness substantially in the high value added ship sector, and is not merely limited to the low-end ship sector. Nonetheless, South Korean's shipbuilding companies such a Hyundai Heavy Industries, Daewoo Shipbuilding and Marine Engineering, and Samsung Engineering maintained their leading position as the largest shipbuilding companies in the world in 2016 (see Figure 7). The future looks very challenging for Korean shipbuilders to maintain their position as China pursues the high value added ship sector relentlessly while keeping production costs low.

Figure 6 Largest Shipbuilding Nations (Jan-Nov 2017)

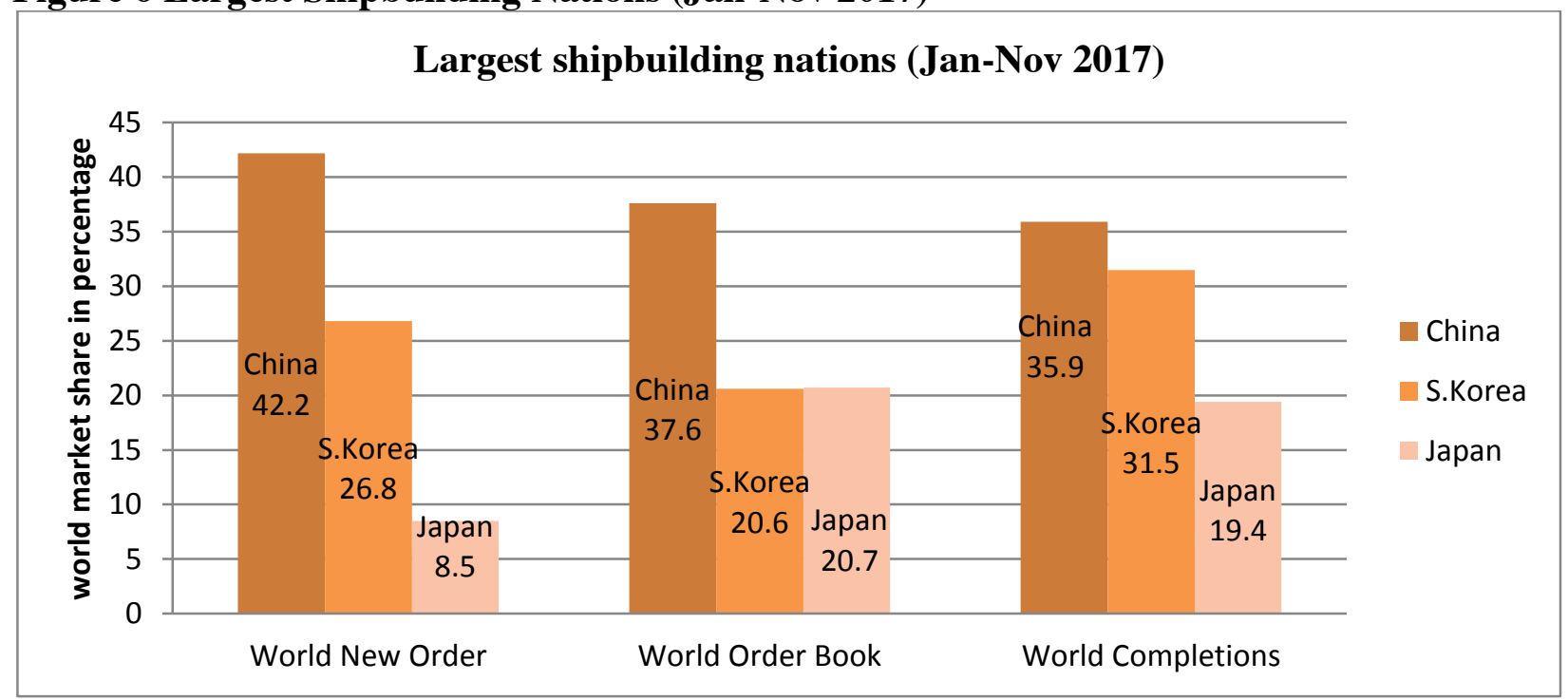

Source: Created by author using data from CANSI 
Figure 7 Leading Shipbuilding Companies Worldwide as of March 2016

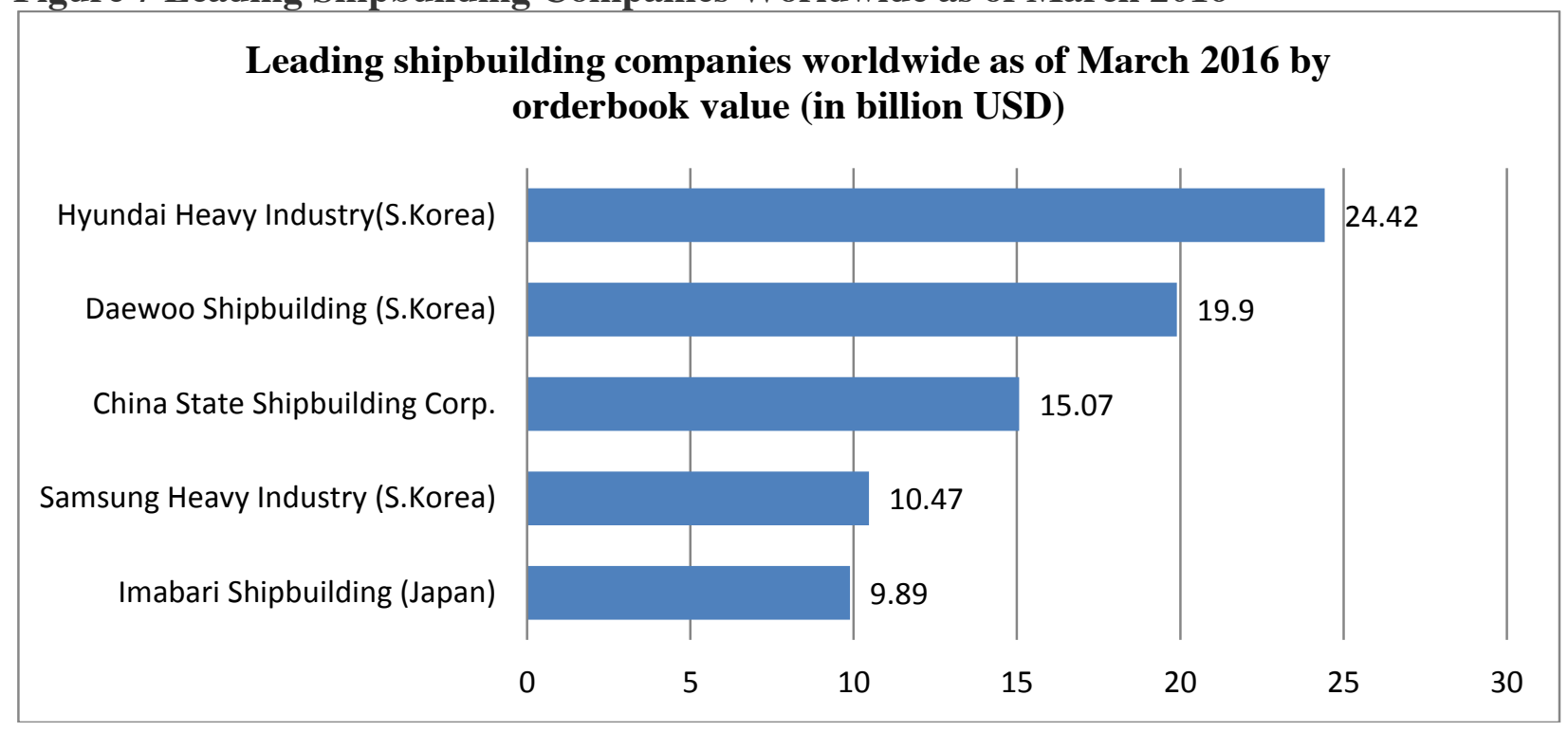

Source: Created by the author using data from Statista ${ }^{12}$

\section{Korean Shipbuilding Industry from 1970s to Present}

Many studies have suggested that the growth of the Korean heavy industries is closely linked to the government roles (for instance Shin, 2009) ${ }^{13}$. Amsden (1989) also stated that "the government played the part of visionary in the case of Korea's first colossal shipyard, and it was responsible for the Big Push into heavy machinery and chemicals in the late 1970 s" ${ }^{14}$ History shows that developing shipbuilding industry was one of the most challenging tasks and therefore the state role was very crucial. With a growth-oriented vertical organization, Korea established itself as the world's largest shipbuilding country within three decades.

In the early 1970s, South Korea was struggling with poverty and repression with the GDP per capita of USD 113 in 1970. To overcome the poverty and improve economic conditions, the Korean government believed that the role of the government was very crucial. Under the capable leadership of President Park Chung Hee, the export-led industrialization policy was launched, which focused on the manufacturing sector. With zero capital and technology, President Park Chung Hee shifted the industrial plan from light industry to technology-oriented industry in the 1970s. The aim was to boost Korean exports and GDP within a short period of time. Under this ambitious plan, the government designated shipbuilding as one of six strategic industries. The other industries targeted for development were iron and steel, nonferrous metals, machinery, electronics and chemicals, all of which were technology oriented and totally new fields in South Korea at that time. The plan was seen as overambitious and seemed unreachable for South Korea, with its backward level of technology, poor management know-how and insufficient capital in the

\footnotetext{
12 Ibid

${ }^{13}$ Kyoung-ho, Shin, "The Steel and Shipbuilding Industries of South Korea: Rising East Asia and Globalization," American Sociological Association, Volume XV, Number 2 (2009): 167-192

14 Amsden, Alice, Asia's Next Giant: South Korea and Late Industrialization, New York: Oxford University Press, 1989
} 
1970s. By working closely with Korean conglomerates, Korean government initiated all the possible mechanisms to help out Korean manufactures with the foundation. From various types of subsidies and policy loans, substantial amount of money was poured into the targeted industries. Industry labour costs were kept extremely low intentionally by the government so that the products and services were highly cost competitive. To raise the quality levels of the technology know-how and management, a government research institute for shipbuilding and ocean studies was established in 1973. The Association of Korean Shipbuilders (KOSHIPA), which is similar to the Shipbuilders Association of Japan, was also formed to provide the industry with various types of information related to domestic and international shipbuilding. ${ }^{15}$ A number of Korean companies (example Samsung, Daewoo and Hyundai) benefited from this policy and eventually became big business groups. The Korean success was seen as a miracle due to its incredible achievement in the manufacturing industries, within a short period of time.

With the promising support from the government, Korean conglomerates grasped the opportunity and competed in the world market. This new path of development in the shipbuilding industry was led by the chaebol leaders of Hyundai, Samsung and Daewoo. These companies began to build large vessels, oil carriers and LNG ships in the early stages, but diversified their products in the later stage.

The earliest shipbuilder, Hyundai Heavy Industry, initially had a plan to construct three medium-scale shipbuilding docks in September 1970, but later, the company drastically shifted its plan to build super-large shipbuilding docks. ${ }^{16}$ This was because the Korean government strongly encouraged shipbuilders to create large vessels to take advantage of the rapidly expanding international market. Hyundai's founder Chung Ju Yong, known for his aggressive business style, built shipbuilding docks with a capacity for ships as large as 500000 GT. The company was successful in building as many as five very large crude oil carriers (VLCCs), all for export to overseas countries. ${ }^{17}$ The Samsung group joined the industry by buying out one of the existing shipbuilders, Woojin, and completed a major shipyard in 1977. The Korean Shipbuilding Corporation also built a major shipyard in 1978 and later merged with Daewoo. ${ }^{18}$ Between 1976 and 1985, the Korean shipbuilding industry grew at a rate of $30 \%$ every year. The number of workers in the industry tripled in the same period. Since then, Hyundai, Daewoo and Samsung Heavy Industry have slowly morphed into giant world shipbuilders and overtook Japanese shipbuilders as the largest shipbuilding companies in 2000. The total number of employees increased exponentially from about 54,000 workers in the year 2000 to 200,000 workers in the year 2017 (KOSHIPA). The majority of them are subcontract manpower and technical and skilled workers. Today, there are nine shipbuilding companies in South Korea, namely Hyundai Heavy Industries Co. LTD; Samsung Heavy Industries Co. LTD; Daewoo Shipbuilding \& Marine Engineering Co. LTD; Hyundai Samho Heavy Industries Co. LTD; Hyundai Mipo Dockyard Co. LTD; STX Offshore \& Shipbuilding Co. LTD; Hanjin Heavy Industries \& Construction Co. LTD; Dae Sun Shipbuilding \& Engineering Co. LTD; and SHINAsb Yard Co. LTD. ${ }^{19}$ Seven Korean companies were among the world's ten largest shipbuilders in 2008, based on order backlogs.

\footnotetext{
${ }^{15}$ Ibid

${ }^{16}$ Dong-Ho Shin \& Robert Hassink, "Cluster Life Cycles: The Case of the Shipbuilding Industry Cluster in South Korea," Regional Studies, 45:10 (2011): 1387-1402, DOI:10.1080/00343404.2011.579594

${ }^{17}$ Ibid

${ }^{18}$ Ibid

${ }^{19}$ KOSHIPA, accessed on Dec 11 2017, available from http://www.koshipa.or.kr/eng/koshipa/koshipa3/index.jsp
} 
Presently, Hyundai Heavy Industries (HHI) maintains its status as the world's biggest shipbuilder and a leading offshore facilities contractor.

Since the 1980s, Korea's shipbuilding industry had experienced three major market crises. The first crisis happened in 1997, second in 2008 and third in 2016. Every crisis affected the industry seriously, which forced shipbuilding companies to go through a process of critical change. For example, in 1997, Daewoo Shipbuilding \& Marine Engineering Co., LTD was separated from the Daewoo group and became an independent entity. ${ }^{20}$ As a result of the restructuring, Korean shipbuilding industry became more competitive and in a better shape financially after 1997. Problematic companies were removed from the market and new and more competitive shipbuilders were created. However, the major crises of 2008 and 2014 told a different story. Major shipbuilders' profits began to slide after the 2008 crisis, attributed to dampened orders and competition from the lower-cost Chinese shipbuilders. Tens of Korean small and medium sized shipbuilders went out of business, leaving only the medium to large firms after 2008. To create its own expertise and to avoid direct competition with Chinese companies in the same sector, Korean shipbuilders ventured into offshore oil rigs, banking on the expanded deep-sea drilling by oil companies as oil prices soared..$^{21}$ The shift to offshore projects created the current problems, particularly for Daewoo and Samsung Heavy Industry, which are heavily dependent on offshore energy projects. When the crude oil price dropped significantly in 2014, Korean shipbuilders were seriously affected with huge financial losses. The current crisis is the most critical one as the majority of the Korean shipbuilders suffered huge losses while at the same time slowly losing the market share to their Chinese rivals. According to CANSI's data, new orders received by Korean shipbuilders plummeted by 82 percent in 2016 in terms of total estimated freight volume for new ships. The sudden plunge of the market had caused serious problems for highly indebted Korean shipbuilders. However, market conditions improved in 2017 as shown in Figure 8. China and South Korea performed much better in 2017 in receiving new orders compared with Japan. New orders received by Japan only increased slightly from 410 million dwt in 2016 to 710 million dwt in 2017. Various reports show that the lack of cost competitiveness is the major problem for the Japanese shipbuilders in securing new shipbuilding orders.

\footnotetext{
${ }^{20}$ Dong-Ho Shin \& Robert, Hassink, "Cluster Life Cycles: The Case of the Shipbuilding Industry Cluster in South Korea," Regional Studies, 45:10 (2011): 1387-1402, DOI:10.1080/00343404.2011.579594

21 "For South Korean Shipbuilders, the Risks Grow," Wall Street Journal, August 24, 2015, available from https://www.wsj.com/articles/for-south-korean-shipbuilders-the-risks-grow-1440439467
} 
Figure 8 Shipbuilding New Orders Received by China, S. Korea and Japan from 2013-2017

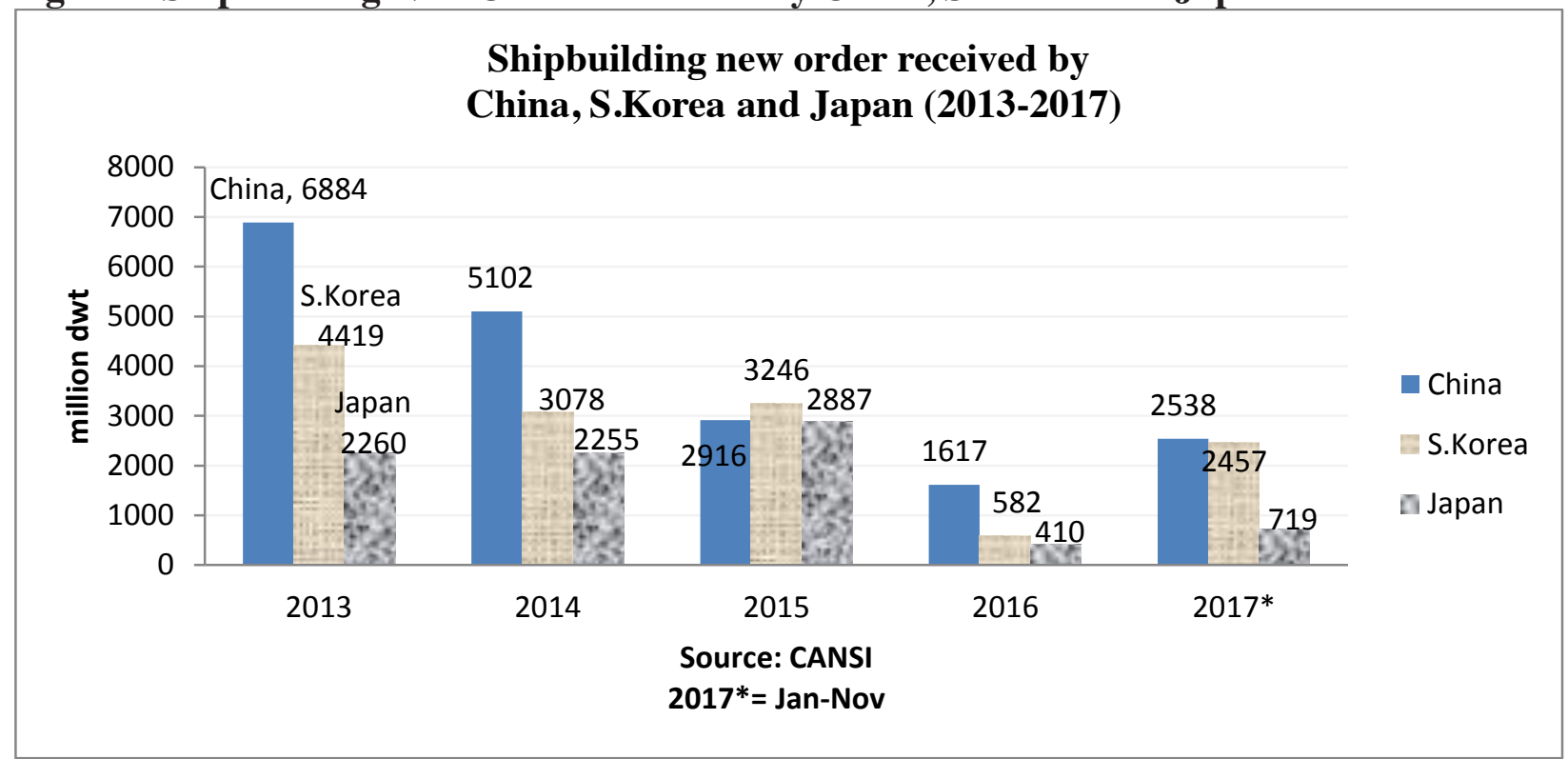

Source: Created by the author using data from CANSI

\section{Impact of the Present Crisis}

As the shipbuilding industry descended into the downtrend cycle since 2014, Korean companies face a wave of challenges, including low new orders, difficulties in fundraising and huge financial loses. ${ }^{22}$ The three largest Korean shipbuilders reported combined losses of 8.5 trillion Korean won in 2015, with Daewoo Shipbuilding alone posting a 5.5 trillion-won loss. ${ }^{23}$ Daewoo Shipbuilding is the worst hit with continuous expanding annual losses from 2013 to 2016 consecutively. In 2016, Daewoo reported a loss of KRW 2734 billion.

The world's fourth biggest shipyard by capacity, Samsung Heavy Industries, was also seriously affected, with massive financial losses for three straight years from 2015 to 2017. It is expected to record an operating loss of 490 billion won in 2017 and a loss of 240 billion won in $2018 .{ }^{24}$ The company's CEO, Park Dae-young who later resigned, took responsibility for missing the sales target and failure in cutting cost. Heavy reliance on offshore projects (two-thirds of its sales) is the main obstacle for the company to recover as the oil and gas industry remains in a state of fluctuation. Compared with Daewoo and Samsung, Hyundai Heavy Industries Co., LTD is in a better condition; the company reported a net profit at KRW89 billion for the year 2016 and an operating profit of KRW46.9 billion is expected for the year 2017. This financial health is reflected in the company's share price as shown in Figure 9. Hyundai Heavy Industries won $\$ 10$ billion worth of combined new orders this year, topping its $\$ 7.5$ billion target and aims to secure $\$ 13.2$ billion worth of new orders in 2018. ${ }^{25}$

23 "New Shipbuilding Orders to Rebound Sharply in 2018: Report," Hellenic Shipping News, October 18, 2016, available from http://www.hellenicshippingnews.com/new-shipbuilding-orders-to-rebound-sharply-in-2018-report/

24 "Samsung Heavy Industries Replaces CEO after Warning of Losses," Wall Street Journal, Dec 11, 2017, available from https://www.wsj.com/articles/samsung-heavy-replaces-ceo-after-warning-of-heavy-losses-1513024398

25 "Hyundai Heavy Plunges on \$1.2bn Rights Offering," Financial Times, Dec 27, 2017, available from https://www.ft.com/content/aa66c7fa-ea2b-11e7-bd17-521324c81e23 
Figure 9 Changes in Share Price of Top Three Korean Shipbuilders since 2013-2017

\begin{tabular}{|l|l|l|l|l|l|}
\hline & $\begin{array}{l}2013 \\
(\mathrm{Dec} 30)\end{array}$ & $\begin{array}{l}2014 \\
\text { (Dec 30) }\end{array}$ & $\begin{array}{l}2015 \\
(\mathrm{Dec} 30)\end{array}$ & $\begin{array}{l}2016 \\
\text { (Dec 30) }\end{array}$ & $\begin{array}{l}2017 \\
\text { (Nov 29) }\end{array}$ \\
\hline $\begin{array}{l}\text { Hyundai Heavy Industries } \\
\text { Co., LTD }\end{array}$ & 244,539 won & 109,424 won & 83,543 won & 138,445 & 148,000 \\
\hline $\begin{array}{l}\text { Samsung Heavy Industries } \\
\text { Co., LTD }\end{array}$ & 33,025 won & 17,315 won & 9,417 won & 9,250 won & 11,950 won \\
\hline $\begin{array}{l}\text { Daewoo Shipbuilding \& } \\
\text { Marine Engineering Co., } \\
\text { LTD }\end{array}$ & 350,000 won & 186,500 won & 50,700 won & $44,800 *$ & 17,950 won \\
\hline
\end{tabular}

Source: Bloomberg

*July 292016

Japanese and Chinese shipbuilders have also been hit by the waning orders resulting from the economic slowdown and a surplus of ships. But the trouble has deepened for South Korean shipbuilders since they began diversifying their operations in 2010 to avoid direct competition with Chinese companies. Consequently the top three South Korean shipbuilders only had one to two years' worth of orders in 2016 to keep the yards busy, compared with 4.5 years of coverage for European ship yards, and 2-3 years of coverage for Chinese and Japanese ship yards. ${ }^{26}$ The worst shortest coverage year hit Korean shipbuilders when they received no orders for making new ships in the yards. Japanese shipbuilders are in a better condition because they have sustained earnings in recent years, mainly from bulk carriers, which are not so high in price and the demand is relatively stable, both at home and abroad. ${ }^{27}$ By contrast, given the small domestic demand and high dependence on global market (90 percent), South Korean shipbuilders tend to pursue orders for vessels with high added values, such as carriers of liquefied natural gas or offshore rigs. ${ }^{28}$ When the oil and gas industry went into trouble, it directly affected the Korean shipbuilding industry. In 2016 April, none of the Korean shipbuilding companies were able to secure a single order; meanwhile, China, armed with low prices, successfully clinched some orders. The revived Japanese shipbuilders also emerged as the "new" competitors with the depreciation of Japanese Yen and big domestic market support. During the crisis period, Japanese shipbuilders received almost half of the new orders from the domestic market, while South Korea was heavily dependent on foreign demands. This has made South Korea more vulnerable when worldwide economy slows down. The industry situation was exacerbated by the collapse of Korean shipping companyHanjing Shipping Co. in 2016, leaving \$14 billion worth of cargos stranded at sea for months. ${ }^{29}$

The pressure to bailout Korean shipbuilders has started to grow as the industry faces liquidity problems. Daewoo was in deeper financial trouble than other domestic shipbuilders; it posted losses for three consecutive years. The Korean state-run bank, KDB, was forced to rescue Daewoo with a \$2.6 billion bailout package in April 2017 when Daewoo was saddled with a

26 "Global Shipbuilding Capacity Set for 20\% Decline Amid New Build Market 'Perfect Storm," Sea Trade Maritime News, October 4, 2017, available from http://www.seatrade-maritime.com/news/asia/26880.html

27 "South Korean Shipbuilders Plan Restructuring," Nikkei Asian Reviews, June 3, 2016, available from https://asia.nikkei.com/Business/AC/South-Korean-shipbuilders-plan-restructuring ${ }^{28} \mathrm{Ibid}$

29 "South Korean Shipbuilder Offered \$2.6 billion Bailout Package," Wall Street Journal, March 23, 2017, available from https://www.wsj.com/articles/south-korean-shipbuilder-offered-2-6-billion-bailout-package-

$\underline{1490237193 ? \mathrm{mod}=\mathrm{mktw}}$ 
liquidity crunch. Daewoo Shipbuilding is majority-owned by state-run banks, and the latter had already given the former a 4.2 trillion won aid package in 2015. According to the Financial Services Commission (FSC) which noted that, "Daewoo would go bankrupt if it failed to redeem 940 billion won of corporate bonds maturing in April 2017. If Daewoo went bankrupt, about 50,000 people would lose their jobs and about 1300 subcontractors could also be adversely affected. The Korean economy could stand to lose revenue to the tune of 48.4 trillion won if Daewoo was not saved." ${ }^{30}$ Thus, it was necessary for the Korea government to provide sufficient funds to improve Daewoo's cash flow and to avoid bankruptcy. As a condition of receiving the bailout package, Korean shipbuilders were required to lay off workers through a painful restructuring. Daewoo Shipbuilding's former head Ko Jae-Ho was sentenced to 10 years in prison for manipulating the company's accounting books in 2013 and 2014; he used falsified accounts to obtain bank loans. ${ }^{31}$

Hyundai Heavy and Samsung Heavy were also struggling to reinforce its competitiveness in the crisis period. To improve company financials, Hyundai Heavy embarked on a rehabilitation plan to reduce its debt from 8.5 trillion won to 6 trillion won by 2018. Samsung Heavy had also plans to sell its hotels and other asset under a 1.5 trillion won management rationalization program. ${ }^{32}$ More than 20,000 workers were laid off by Hyundai Heavy, Samsung Heavy and Daewoo Shipbuilding since the downturn began in 2014. To improve the competitiveness in its shipbuilding core business, Hyundai Heavy Industries divested the non-core businesses and restructured the corporation into four independent entities in the early 2017: shipbuilding, electronics, construction equipment and robotics. On December 26 2017, Hyundai Heavy announced a fund raising plan by selling new shares to raise US $\$ 1.2$ billion. The money will be used to repay debts and to invest in research and development. ${ }^{33}$ Consequently, the share price of Hyundai Heavy dropped significantly, as much as 29 percent, the largest decline since the company was listed on South Korea's main board in 1999. The major state shareholders of Hyundai Heavy are very concerned with the deteriorating financial situation of the company. Overall, the future looks very challenging for Korean shipbuilders as global market demand for ships remains sluggish, coupled with competition from Chinese and Japanese rivals.

\section{Challenges from China and Japan}

With the competition from Chinese rivals coupled with a market slowdown, and the revival of Japanese shipbuilders, Korean shipbuilders had to struggle with an uphill task. By riding on the advantage of the weak yen since 2013 and increasing demand for eco ships, Japanese shipbuilding companies showed strong signs of business revival. Tough Japanese players such as Imabari Shipbuilding and Mitsubishi Heavy Industries managed to enlarge their market shares with the introduction of high fuel-efficient ships and improved designs. For instance, Mitsubishi Heavy

\footnotetext{
30 "S. Korea's Daewoo Shipbuilding to get Fresh \$3.6b Bailout," Straits times, March 24, 2017, available from http://www.straitstimes.com/business/s-koreas-daewoo-shipbuilding-to-get-fresh-36b-bailout

31 "South Korea Throws Shipbuilder Daewoo New \$6 Billion Lifeline," Industry Week, March 23, 2017, available from http://www.industryweek.com/treasury-cash-management/south-korea-throws-shipbuilder-daewoo-new-6billion-lifeline

32 "South Korean Shipbuilders Plan Restructuring," Nikkei Asian Review, June 3, 2016, available from https://asia.nikkei.com/Business/AC/South-Korean-shipbuilders-plan-restructuring

33 "Hyundai Heavy Plunges by Record on \$1.2 Billion Sale Plan," Bloomberg, Dec 26, 2017, available from https://www.bloomberg.com/news/articles/2017-12-26/hyundai-heavy-plans-to-raise-1-2-billion-in-sale-of-newshares
} 
Industries constructed green high-tech LNG carriers that are capable of saving 20 percent fuel. Cargo ships constructed by JMU's Kure shipyard require 15 percent less horsepower to carry each container compared with those made by other shipbuilders. ${ }^{34}$ When the world environmental regulations are tightened in 2020 to limit emissions of sulfur oxide and other pollutants from ships, it is expected that Japanese shipbuilders will be benefit from their environmental technology. ${ }^{35}$

As the global shipbuilding orders slump due to a worldwide market downturn, the Korean shipbuilding industry is vulnerable to a greater financial shock than its Japanese and Chinese counterparts. The main disadvantage of South Korea is the lack of domestic market support; Korea is a smaller ship owning nation compared with Japan and China which are the second and third largest ship owning nations in the world respectively. As an economy that is dependent heavily on international market, South Korean shipbuilders obtain about $90 \%$ of their work from global clients, while Japan received 50\% new orders from domestic clients in $2016 .{ }^{36}$ For instance, Japanese shipbuilding companies secured new orders for a total of 48 vessels between January and November 2015, at least 40 of which were reportedly ordered by Japanese shipping companies like Mitsui OSK Lines (MOL). ${ }^{37}$ The shipyard at Japan Marine United (JMU) has been kept busy since 2014; the booming business is attributed to the sales order of 15 large cargo ships from Nippon Yusen, a top Japanese marine transport company. ${ }^{38}$ According to a source at Hyundai Heavy Industries, "Japanese shipyards are holding on because they have lots of orders from their domestic shipping companies, but Korean shipyards haven't received a single order for a new ship from domestic shipping companies over the past few years since every shipping company has been facing a severe liquidity crisis. ${ }^{39}$ An analyst from Korea Institute for Industrial Economics and Trade (KIET) named Hong Seong-in commented that, "When the global shipbuilding industry faces a shortage of orders, domestic orders can serve as something of a safety valve." This indicates that a lack of support from the domestic market is one of the major comparative disadvantages for Korean shipbuilders.

With more than 500 shipbuilding companies in China, Chinese shipbuilders constitute a bigger challenge to South Korea compared with Japanese competitors. With the aggressive state support since 2000, Chinese shipbuilders had successfully overtaken South Korea as the largest shipbuilding nation in 2010. While Japanese shipbuilders are excellent in the environmental technology segment, Chinese competitors beat the Korean rivals through their cost competitiveness. With the cheaper Chinese yuan and lower labour cost, Chinese shipbuilders usually offer a 25-30 percent cheaper price to their clients than their Korean rivals. Chinese companies require only 12 percent of the total cost to secure an order, while the best South Korean company asks for a deposit of between 30 and 35 percent. ${ }^{40}$ The large difference in earnest money has been the primary factor for South Korean shipbuilders to lose its market share to China. According to Samsung Securities analyst Han Young-soo, "Chinese companies, armed with lower labour costs, have always had an edge over Korean rivals, and the yuan's weakness will only help

\footnotetext{
34 "Year 2019 problem' Looming over Japanese Shipbuilders," Nikkei Asian Reviews, Jan 19, 2017, available from https://asia.nikkei.com/Business/Trends/Year-2019-problem-looming-over-Japanese-shipbuilders?page=1

35 Ibid

36 "South Korean Shipbuilding Looming over a Cliff as it's Overtaken by Japan," Hankyoreh, Jan 5, 2017, available from http://english.hani.co.kr/arti/english_edition/e national/777534.html

${ }^{37}$ Ibid

38 "Year 2019 Problem' Looming over Japanese Shipbuilders," Nikkei Asian Reviews, Jan 19, 2017.

${ }^{39}$ Ibid

40 "Chinese Shipyards to Challenge South Korea's Dominant Rivals," China Daily, August 27, 2014, available from http://usa.chinadaily.com.cn/epaper/2014-08/27/content_18496602.htm
} 
raise their bargaining power." ${ }^{41}$ Labour cost makes up 30 percent of the total shipbuilding production costs. As there is no significant difference between countries in the cost of materials, workers' productivity and wages act as a decisive factor in the cost difference. South Korean companies will have a hard time competing with those from China since it is almost impossible to beat the latter in terms of cost. In addition, with the enforcement of rigid labor market regulations in South Korea, it is difficult for Korean companies to cut labor cost through massive layoffs. According to the latest statistics of Dec 2017, China has captured 42 percent of the world market share for new orders compared with 35 percent in 2016. The world market share of South Korea has been shrinking in recent years, and this is not a good sign for the future of South Korean shipbuilders.

\section{Conclusion}

With rising from less than one percent of completions in 1975 to nearly 40 percent of world market share in 2008, South Korea shipbuilding industry was once known as the biggest star in the industry. However, with the shrinking market share year after year, the golden age for South Korean shipbuilders seems to be over. With better cost competitiveness and aggressive state supports, China has overtaken South Korea as the largest shipbuilding nation. History informs us that the geographical shift in the market happened due to one major reason. Cost competitiveness has always been the decisive factor for determining the success or failure in the industry. Through cost competitiveness, South Korea overtook Japan in 2000 and Japan overtook Britain in 1950s. To win back the market share, it is imperative for Korean shipbuilders to cut down production cost substantially. It will surely be painful, but there is not much of a choice left. Given the current market situation, it will be very challenging for Korean shipbuilding industry to regain its status without a large scale restructuring. Currently, Hyundai Heavy Industries is a little bit better off, but Daewoo Shipbuilding and Samsung Heavy are struggling to stay afloat. Certainly the continuous support by the Korean government is extremely important in helping the industry to regain its strength. Nonetheless, how long more will the industry need such financial bailouts? For the long term, Korean shipbuilders have no choice but to stand on their own feet to reclaim the status of South Korea as the world's best shipbuilding nation.

\section{References}

Amsden, Alice, Asia's Next Giant: South Korea and Late Industrialization, New York: Oxford University Press, 1989.

An Assessment of Maritime Technology and Trade, Washington, D.C.: U.S. Congress, Office of Technology Assessment, OTA-O-220, October 1983, p.87

Todd, Daniel, The World Shipbuilding Industry, Volume 26 of Routledge Library Editions: Transport Economics Series, 2017.

Shin, Dong Ho \& Robert, Hassink, "Cluster Life Cycles: The Case of the Shipbuilding Industry Cluster in South Korea, Regional Studies, 45:10(2011): 1387-1402, DOI:10.1080/00343404.2011.579594

41 "For South Korean Shipbuilders, the Risks Grow," Wall Street Journal, August 24, 2015, available from https://www.wsj.com/articles/for-south-korean-shipbuilders-the-risks-grow-1440439467 
Shin, Kyoung Ho and Paul S. Ciccantell, "The Steel and Shipbuilding Industries of South Korea: Rising East Asia and Globalization," American Sociological Association, Volume XV, Number 2 (2009): 167-192. https://doi.org/10.1016/j.tre.2013.10.001

Liping, Jiang, Erik, Bastiansen, Siri P.Strandenes, "The International Competitiveness of China's Shipbuilding Industry," Transportation Research Part E: Logistics and Transportation Review, volume 60 (December 2013): 39-48. http://dx.doi.org/10.1016/j.tre.2013.10.001

Marion, Eich-Born \& Robert, Hassink, "On the Battle between Shipbuilding Regions in Germany and South Korea," Environment and Planning A, volume 37 (2005):635-656

$\mathrm{Mu}$ Yang and Hong Yu, China's Industrial Development in the $21^{\text {st }}$ Century, Singapore: World Scientific Publishing Co. Pte. Ltd

Steers, Richard, M., Made in Korea: Chung Ju Yung and the Rise of Hyundai, New York: Routledge, 2013.

Krishnan, S. Navaneetha, Prosperous Nation Building through Shipbuilding, National Maritime Foundation, 2013.

Nagatsuka, Seiji Structurally Changing South Korea's Shipbuilding Industry and Future Prospects thereof: Can South Korea Overtake Japan? Japan Maritime Research Institute, Issue 57 of JAMRI report, June 1999. 